\title{
Diffuse large B-cell lymphoma in the psoas muscle
}

\author{
Tatsuya Fujikawa, ${ }^{1}$ Yasunori Kawachi ${ }^{2}$
}

${ }^{1}$ Mitoyo General Hospital, Kan-onji, Japan

${ }^{2}$ Kaisei General Hospital The Taijukai Foundation, Sakaide, Japan

\section{Correspondence to} Dr Tatsuya Fujikawa, tfujikawa-gi@umin.ac.jp

Accepted 10 April 2015

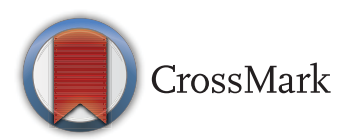

To cite: Fujikawa $T$, Kawachi Y. BMJ Case Rep Published online: [please include Day Month Year] doi:10.1136/bcr-2015209898

\section{DESCRIPTION}

A 78-year-old man with a history of aphasia caused by cerebral infarction came to our hospital because of persistent progressive left lower back pain for 1 week, which had radiated through the left buttock and down the left thigh.

On clinical examination, he was in the right lateral decubitus position on a bed in a psoas posture with a body temperature of $36.7^{\circ} \mathrm{C}$. Laboratory results revealed leucocytosis $\left(9.71 \times 10^{9} / \mathrm{L}\right)$, and elevated lactate dehydrogenase $(415 \mathrm{IU} / \mathrm{L})$ and creatine kinase $(255 \mathrm{IU} / \mathrm{L})$ levels.

Contrast-enhanced CT of the abdomen after plain CT revealed a swollen left psoas muscle that was enhanced homogeneously (figure 1, arrows), indicating tumours in the left psoas.

A pathological examination of the left psoas muscle by CT-guided needle biopsy was conducted. $\mathrm{H} \& \mathrm{E}$ (figure 2) and additional immunohistochemical staining results (positive for CD20, weakly positive for CD10, negative for CD3 and terminal deoxynucleotidyl transferase, and a high MIB-1 index) were consistent with diffuse large B-cell lymphoma (DLBCL).

Although the primary origin of DLBCL was unclear, the left psoas muscle was most likely compared with the swollen lymph nodes in the perirenal space and para-aorta ventral to left psoas muscle because of its considerably large size.

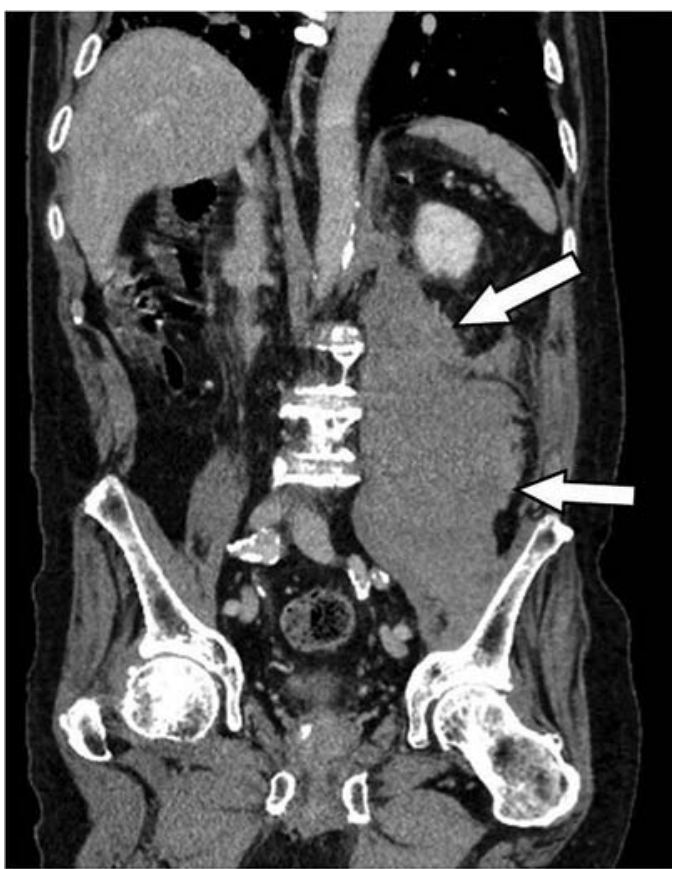

Figure 1 A contrast-enhanced CT image of the abdomen showing a swollen left psoas muscle that was enhanced homogeneously (arrows).

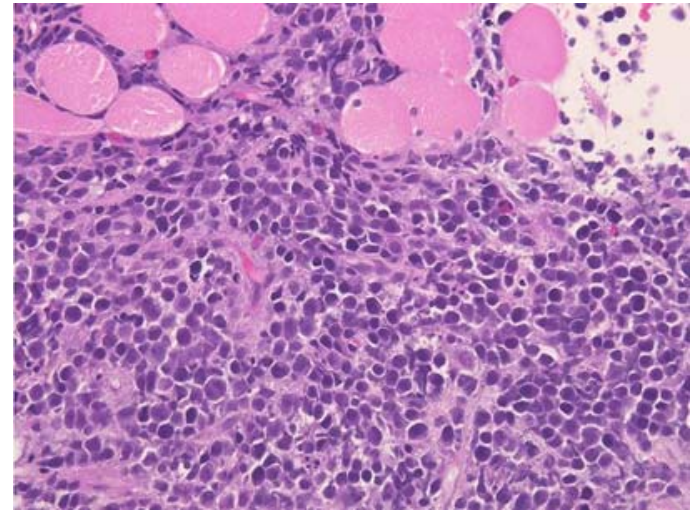

Figure 2 A biopsy specimen of the psoas muscle demonstrating a tumoural and diffuse polymorphic infiltration by large lymphoid cells (H\&E stain; magnification $\times 40$ ).

The patient's family requested only palliative care instead of chemotherapy due to the patient's advanced age and dementia. His clinical condition gradually deteriorated, he developed multiorgan system failure and died 43 days postadmission.

Non-Hodgkin lymphoma (NHL) is the most common type of lymphoma ${ }^{1}$; with DLBCL being its most predominant type. ${ }^{1}$ However, this report describes a rare case of NHL manifesting in primary skeletal muscles, which accounts for only $0.1 \%$ of all lymphomas. ${ }^{2}$ The extranodal manifestations of DLBCL generally affect the gastrointestinal tract or bone marrow and less commonly affect the skeletal muscle. ${ }^{1}$ Furthermore, in most cases of skeletal muscle DLBCL, upper arm muscles and glutei are reported to be predominantly affected. ${ }^{1}$ Hence, the present case of DLBCL in the psoas muscle presents an extremely rare manifestation. Although there are no significant data on prognosis of soft-tissue DLBCL, it appears to present a relatively poor prognosis compared with nodal DLBCL. ${ }^{3}$ The recommended treatment for advanced stage DLBCL is systemic chemotherapy with the recombinant anti-CD20 antibody

\section{Learning points}

- The differential diagnosis of soft-tissue masses should include metastatic carcinoma, purulent abscesses and malignant lymphoma.

- Skeletal muscle is a rare primary location for non-Hodgkin lymphoma (NHL), accounting for only $0.1 \%$ of all lymphomas.

- Raising awareness of NHL as a differential diagnosis for psoas muscle enlargement would improve tissue biopsy analysis. 
rituximab. ${ }^{4}$ Given the aggressive nature of DLBCL, the differential diagnosis of soft-tissue masses should include metastatic carcinoma, purulent abscess and malignant lymphoma. ${ }^{5}$

Acknowledgements The authors are grateful to Dr Katsuya Miyatani at Mitoyo General Hospital for the histopathological examinations, and Dr Hironori Kurokawa at Mitoyo General Hospital for the CT-guided biopsy.

Contributors TF wrote manuscript and contributed to discussion. YK contributed to discussion.

Competing interests None declared.

Patient consent Obtained.

Provenance and peer review Not commissioned; externally peer reviewed.

\section{REFERENCES}

1 Bourdeanu L, Menon R, Somlo G. Diffuse large B-cell lymphoma with calf muscle localization. Case Rep Hematol 2011;2011:292494.

2 Alekshun TJ, Rezania D, Ayala E, et al. Skeletal muscle peripheral T-cell lymphoma. J Clin Oncol 2008;26:501-3.

3 Derenzini E, Casadei B, Pellegrini C, et al. Non-hodgkin lymphomas presenting as soft tissue masses: a single center experience and meta-analysis of the published series. Clin Lymphoma Myeloma Leuk 2013;13:258-65.

4 Sehn LH, Donaldson J, Chhanabhai M, et al. Introduction of combined CHOP plus rituximab therapy dramatically improved outcome of diffuse large B-cell lymphoma in British Columbia. J Clin Oncol 2005;23:5027-33.

5 Emori M, Kaya M, Takahata S, et al. Anaplastic lymphoma kinase-negative anaplastic large cell lymphoma with extra-nodal involvement of the thigh muscle: a case report. J Med Case Rep 2014;6:9.

Copyright 2015 BMJ Publishing Group. All rights reserved. For permission to reuse any of this content visit

http://group.bmj.com/group/rights-licensing/permissions.

BMJ Case Report Fellows may re-use this article for personal use and teaching without any further permission.

Become a Fellow of BMJ Case Reports today and you can:

- Submit as many cases as you like

- Enjoy fast sympathetic peer review and rapid publication of accepted articles

- Access all the published articles

- Re-use any of the published material for personal use and teaching without further permission

For information on Institutional Fellowships contact consortiasales@bmjgroup.com

Visit casereports.bmj.com for more articles like this and to become a Fellow 